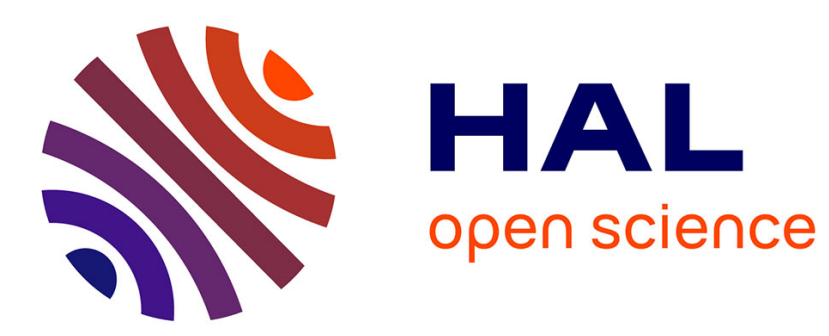

\title{
Exclusionary Politics and the Question of National Belonging
}

\author{
Kay Anderson, Affrica Taylor
}

\section{To cite this version:}

Kay Anderson, Affrica Taylor. Exclusionary Politics and the Question of National Belonging. Ethnicities, 2005, 5 (4), pp.460-485. 10.1177/1468796805058095 . hal-00571848

\section{HAL Id: hal-00571848 \\ https://hal.science/hal-00571848}

Submitted on 1 Mar 2011

HAL is a multi-disciplinary open access archive for the deposit and dissemination of scientific research documents, whether they are published or not. The documents may come from teaching and research institutions in France or abroad, or from public or private research centers.
L'archive ouverte pluridisciplinaire HAL, est destinée au dépôt et à la diffusion de documents scientifiques de niveau recherche, publiés ou non, émanant des établissements d'enseignement et de recherche français ou étrangers, des laboratoires publics ou privés. 


\title{
thnicities
}

Copyright $\odot 2005$ SAGE Publications (London, Thousand Oaks, CA and New Delhi) 1468-7968

Vol 5(4): 460-485;058095

DOI:10.1177/1468796805058095

www.sagepublications.com

\section{Exclusionary politics and the question of national belonging}

\author{
Australian ethnicities in 'multiscalar'focus
}

\section{KAY ANDERSON}

University of Western Sydney

\section{AFFRICA TAYLOR \\ University of Canberra}

\begin{abstract}
This article builds on recent efforts to cast the understanding of ethnic and racialized tensions less in terms of a coarse logic of racism than within an analytical frame of struggles over national belonging. This theme is developed with respect to intercultural relations in Australia, in all the complexities of its white settler, migrant, and indigenous formations. The article develops a 'multiscalar' focus that takes in the global circuits of movement and relationship linked to British colonialism and international migration, through to contests over the meanings, management and stewardship of local places. In so doing, we also highlight some contextually specific versions of 'whiteness' whose various mobilizations help to undo a sense of their fixed status as core attributes of Australian nationhood. The article concludes with a case from Jervis Bay, New South Wales, where contested imaginings of, and investments in, appropriate land uses, have given rise to disputes that are productively conceived in terms of a multiscalar politics of national belonging. Although thus grounded in the circumstances of Australian culture, we believe the core argument can be extended (with all the normal caveats) to other ex-British colonial, immigration nations.
\end{abstract}

KEYWORDS Australia $\bullet$ belonging $\bullet$ geographies $\bullet$ postcolonial $\bullet$ postnational - whiteness 


\section{INTRODUCTION}

In what follows, we wish to argue for a historicized and post-national frame of reference for theorizing pluralism in Australia. The starting point for this argument is a 'multiscalar' imagination that undoes the familiar script of a national body composed of majority and minority cultures. Without denying the power of the nation state as a unit of social integration, shaping the rights of citizens in often highly uneven ways, we wish to critically conceive the Australian nation-building process within the global and historical circuits of colonialism and transmigration. This manoeuvre enables us to locate racialized 'whiteness', or at least Australia's variant of this mobile cultural formation, within a historicized field of making and struggle alongside its diverse 'ethnic others' and indigenous people. Using these two lines of argumentation - the one developing a multiscalar account of the making and transformation of Australian nationhood, the other highlighting the changing inflections of, and fragilities within Australian whiteness - we seek to displace the popular sense of a unitary whiteness from its exceptional positioning vis-à-vis all other groups. These groups are typically and unhelpfully conceived in the Australian context - in both classically racist formulations of white nationhood and the liberal discourse of 'multicultural recognition' - as in-comers to a prior national ancestral space, impacting a spatialized body from without.

\section{POST-NATIONALITY AND PLURALISM: THE AUSTRALIAN CASE}

The foundational narratives of nationhood that characterize contemporary Australia have tended to work with a series of related premises. There are at least three as follows: (a) a norm of unmarked whiteness that forgets its own contested history and variability across time and space; (b) a liberal notion of multiculturalism, conceived as the accommodation of majoritywhite and minority-non-white cultures; and (c) a notion of nation as a territorialized space, as distinct from nation as de- and re-territorialized in and through variously diasporic lives. Such settled and profoundly undertheorized discourses of nationhood derive, at least in part, from some equally conventional thinking about the ethnicities that make 'us' up as a nation. Typically, such identities are crudely and hierarchically organized into the following categories: first, the Anglo-Celtic Australians who collectively claim the status of 'settler' or 'host' and acknowledge their own ethnic specificity only as their social domination comes under challenge; second, those characterized as 'migrants' - the non-Anglo 'ethnics' of the likes of 
Greek and Iranian background who are rarely seen as generative of Australian nationhood, and more likely to be thought of as 'new' Australians; and third, indigenous people whose prior occupation of the Australian landmass is, typically, an anxiously buried awareness. In the academy, these distinctions have been inscribed in discrete knowledge (and policy) spheres of Ethnic and Racial Studies on the one hand, and Indigenous Studies on the other, with white settler occupying that radically unmarked field beyond both such others, called the 'mainstream'.

This article carries on in the vein of the numerous scholars now seeking to disturb the foundation - moral and ontological - of claims to a core national white culture in Australia (e.g. Hage, 1998, 2003; Stratton, 1998; Cohen, 2003). As suggested above, it tackles this challenge by investigating how, in the case of Australia, British colonialism forged a distant variant of Anglo-Celtic privilege that has existed in tension with other white (and non-white) migrant ethnicities, as well as the indigenous peoples variously oppressed by all such diasporic groups. First, however, some brief comments are helpful concerning this article's interest in the spatialities of national belonging.

\section{The spatialities of national belonging}

Occupying as it does a certain 'in-between' location in time and space, Australia calls into view the many complex cultural dynamics of postcoloniality. In its current time-space positioning, Australia belongs to neither its Anglo-centered past nor to an assuredly postcolonial or Asian future. In this liminal location, where hints of a republic have prompted discussion and debate about 'rights to belong' among white settler, migrant, and indigenous groups, there are possibilities for thinking across the spaces of knowledge that have framed theorizations of pluralism more generally. To that end, it is productive to recast the multicultural ideal from its exterior relation to the nation - as something that inheres in the bodies of alien visitations - by focusing on the contested claims to national belonging of the spaces that are made to stand as 'nations'.

Although it is the case that deliberations over membership and voice within the Australian nation have historically been enacted in the clauses of national and international policy discourse, they are also played out in the local spaces of lived experience - not least, in intercultural contests over the meanings, management and stewardship of local places. We seek to evoke a series of nested geographies here, a fluid and entangled set of 'spacings' that are unmoored from any fixed referent in discrete scales national, international, local and otherwise - and which need to be conceived as co-constitutive. Such 'spacings' are not fixated to 'here' or 'there' as if distributed on a surface, but, instead, are always 'in process, in time' to recall Abrams' (1982) call for a historical sociology some decades 
ago. Their complex and relational 'coming into being' is the focus, in the vein of Hacking's (2002) more recent call for Historical Ontology. We thus proceed from Massey's (2000: 228) evocation of space as a 'contemporaneity of trajectories', produced out of the traces left by a multitude of histories, to argue that the politics and fantasies that inhere within nation building are simultaneously and reciprocally global/national/local. This is also to recall, from quite some time ago now, de Certeau's (1984: 117) notion of space as composed of 'the intersections of mobile elements'.

This interest in the conjunctions of time and space is by no means new and figures centrally in the literature on the restructurings of globalization and neoliberalism. In the wake of new institutions like the World Trade Organization (WTO) and the International Monetary Fund (IMF) and the growing importance of supranational institutions like the European Union (EU) and Association of Southeast Asian Nations (ASEAN), attention has focused on the reconfiguration of politics and economy on various spatial scales (e.g. Swyngedouw, 1997; Brenner, 1998). Typically, this shifting governance is conceived as an uneven, and deeply contested, process of de- and re-territorialization that is highly structurally selective in the interests of powerful actors. Such economic and political restructurings are often conceptualized in the (awkward) language of the 'glocal' to capture their multiscalarity, from local housing movements and placemarketing strategies by councils, through national-level financial deregulation measures, to international corporatization, at the intersection of which have been provoked what are sometimes called 'glocalized' protests for democratization (Kohler and Wissen, 2003). These social movements are said to direct their actions at specific local places, while simultaneously confronting global power relations.

Here, we offer a less explicitly politicized but no less dynamic reading of multiscalarity, one that indexes a distinctively critical and probing approach to debates surrounding national belonging. Macro-global projects such as colonialism and transnational immigration do not simply (or even complexly) tattoo their mark on the surface of our towns, cities, and countrysides. Equally, local instances of intercultural encounter/tension are more than simply 'examples' or 'cases' that can be 'read off' from those international projects. If we think of space, to borrow from Raymond Williams, as a complex federation of 'emergent, dominant and fading horizons' (quoted in Fischer, 1999: 456), we get closer to a more embedded time/space understanding of the conflictual and creative tensions over belonging that shape intercultural relations. We seek to evoke these later on in the article in a discussion of a zoning dispute as a 'point' of global/national/local connectivity, one that spills over any discrete local or national or global scalar framing. 


\section{SPECIFYING AUSTRALIAN WHITENESS: DISPOSSESSION AND DISPLACEMENT}

Theorizing the Australian present demands precisely this kind of historically-attuned and spatially-dense imagining of the constitutive differences that make 'us' up. This imagination works to uncover from obscurity, and critically 'retell' (Hall, 1994: 393) the exclusionary politics that have inhered in the process of assembling a mainstream of citizens who unreflexively imagine themselves as national 'hosts'. Over the last decade, for example, we have witnessed the recurring theme in media and policy discourse that the body of the nation is 'under siege' from escalating flows of immigrants who in time - so it is thought - must become 'integrated' into the space of the nation in the interests of 'social cohesion'. In the case of asylum seekers, the concerns are that they could become either too numerous and/or too different to be accommodated without disrupting the spatial imaginary of the Australian nation. The idea of a traffic in people, thought to be all the more presumptuous in the case of smuggling rings, has set up a profound sense of threat to the very idea of territory as a sovereign space over whose borders a certain authorized public has the sole right of movement, ownership and voice.

In Australia, those unauthorized arrivals that have successfully evaded coastline patrols in a series of heightened moments since the Vietnamese 'boat-people' of the 1970s, have aroused collective anxieties about the vulnerability of the land/sea border to penetration. Anxieties reached a peak in late 2001 around the 'Tampa affair', when the conservative Howard government intercepted and denied 433 rescued asylum seekers entry into Australia and precipitated an international controversy (Mares, 2002). To use Perera's (2002) terms, this moment at which Howard drew 'a line in the sea' to keep asylum seekers out, was one of moral crisis for Australia. 'Border protection' (Vanstone, 2003) became the catch-cry that justified an immediate series of official exclusionary practices. These included such radical measures as emergency retrospective legislation to enact the strategic excision of certain north-western Australian off-shore territories, and the so-called 'Pacific Solution', whereby boatpeople seeking asylum in Australia were diverted, 'accommodated'/detained and processed in small, poor, neighbouring Pacific nations (Nauru and Papua New Guinea) in exchange for significantly increased financial development assistance (Brennan, 2003: 106-12). These extreme 'border protection' measures are underpinned by and also generate what Hage (2003: 31) describes as 'the imaginary of paranoid nationalism', and have since successfully deterred the flow of asylum seekers.

Of course, paranoid nationalism is not exclusive to Australia. However, in light of the Australian government's overreaction to what was in relative 
terms a very small number of asylum-seeking refugees, we contend that these most recent expressions of national anxiety can be productively thought across a series of geographical nestings that are specific to the Australian context. These nestings, or spacings, link the current perception of an explicitly external threat of refugee invasion with an internalized settler-society anxiety that is embedded within the vexed and unreconciled colonial origins of the Australian nation and the disposition of its immigrant population.

As many Australian scholars have noted (e.g. Jacobs, 1996; Reynolds, 1998; Langton, 2003), indigenous dispossession casts a shadow over the unproblematic heroic narratives of 'white settlement' and continues to haunt the discourses of a benign and united sovereign nation. More than a century after federation, an apology for past injustices to indigenous Australians remains an 'unsayable' act for the Howard government (Gooder and Jacobs, 2000). As a symbolic disavowal of the 'black history' of this nation, Howard's refusal to say 'sorry' suggests a kind of historical defensiveness that is analogous with defending the assumed-to-be-white space of the nation (see also Shaw, 2001). In reference to indigenous dispossession as both the foundational act that secured white sovereignty and the residual effect that continues to disturb it, Gelder and Jacobs (1998: 151) describe the resultant 'uncanny' and disquieting sense that '... one can never be fully in possession of place: one is always in a state of (dis)possession, in the sense that neither possession nor dispossession are fully realisable categories'. For white-settler descendent Australians in particular, but to some extent for all non-indigenous Australians, the desire to belong that propels the nation-building process is thus counterposed by the dispossession of Indigenous Australians. Read (2000) has articulated many of the ambivalences and tensions that underlie this relationship in his musings on the pathways for non-indigenous belongings in contemporary Australia.

Within the framings of this constitutive relationship, deliberations upon the nature of white belongings burgeoned following the belated recognition of Native Title during the Keating years of Labor government (1991-96). Not only did the recognition of prior indigenous ownership expose the precarious foundations of white settler sovereignty, it also unleashed a tide of public anxieties over the lack of 'certainty' about the currency of white land tenure. In a series of amendments to the Native Title Act in 1998, Howard's conservative government moved to 'swing the pendulum back' (cited in Bachelard, 1997: 71) by firming up the rights of white pastoralists and mining companies and diminishing those of native title claimants (Jonas, 2000). These legislative moves to 'firm up', 'secure' and 'protect' the internal territories of white national interests were echoed a few years later by the same government's enactments to 'protect' the external borders against a perceived foreign threat to the (white) national body. 
These roving settler-society anxieties that range across the spacings of internally and externally located threats, are compounded by a feeling of cultural and geographical isolation and displacement from the British imperial centre. Ang (2003) notes that '. . . white racism in the Australian context has peculiarities, and it has to do with the spatial dimension of this settler project', including an '... antipodean sense of place' (p. 54) which manifests as 'spatial anxiety' (p. 57). One of the manifestations of this spatial anxiety appears to be uncertainty about the very source of insecurity. In that regard, we might add here that Australian whiteness, as an essentially unstable postcolonial position, is articulated from the nexus of indigenous dispossession and the cultural and geographic displacement of its Anglo/Celtic immigrant population.

Further apprehensions regarding the tenancy of Australian whiteness can be traced back to the cultural politics of nation building that began at Federation. Nicholl (2001: 110) has noted the significance of the fact that 'the first session of the national parliament was spent formulating legislation to ensure the "purity" of the white Australian race' - the Immigration Restriction Act (1901) and subsequently an Assimilation Policy to deal with the anomalies of surviving Aboriginal people as well as Chinese and other successive waves of non-Anglo immigrants. Such efforts belie their intent and highlight the obvious fact that an unambiguously white Australian nation was always going to be untenable. Nevertheless, the official rhetoric of white Australia was sustained by successive governments in a sevendecade relay of White Australia policy. Peculiar to Australian settler society, this overt privileging of whiteness within the official discourse of national identity has made an indelible mark. By the time it was finally replaced in the early 1970s with the Multicultural Australia Policy, white assimilation had imprinted itself upon the 'national imagination' in ways that multicultural Australia has subsequently failed to do (Johnson, 2002: 79).

Certain benign facets of ethnic difference, such as Asian cuisine, have, however, and for some decades now, been variously welcomed as a so-called 'contribution' to, or 'enrichment' of, a cosmopolitan Australia. As Perera and Pugliese (1996: 110) point out, 'the culinary, with its economy of enrichment and incorporation, signifies the palatable and always aestheticized element of multiculturalism precisely because it still effectively reproduces an assimilationist economy of cultural containment and control'. Notwithstanding the close identification of Howard's Liberal Party with opposition to multiculturalism, immigration and what, in 1996, he famously called 'the Aboriginal industry', Howard too now endorses the idea of ethnic diversity as an array of exotic attributes that assumed-to-be-white nationalists might be enriched by (Howard, 1999a). This is the kind of conditional multiculturalism that Ghassan Hage (1998) has argued against in his provocative critique of 'white multiculturalists' in Australia. Hage claims that no less than anti-immigration measures, white multicultural discourse is effected by 
the same differentiation between ethnic others who are 'managed' on the one hand, and the agency of white 'managers' - or those who read themselves into the white fantasy script - on the other. That is, those who have afforded themselves the 'national governmental right', as Hage states it, to script the nation.

There are a number of analytical strategies for unsettling the ontological security of the position of 'host' in Australia. One manoeuvre is to critique the presumption of 'white settler' Australians that they naturally possess a right of birth and destiny to claim voice over a national space. Another linked, but less familiar tactic entails digging deeper into the buried epistemological premise that there is a stable and fixed correspondence between nation-boundedness and national identity. Such territorializing concepts of identity (Malkki, 1992) connect territory and national identity in the essentialized images of roots, trees, stock, and ancestry. When conceived, however, in terms of the entangled trajectories that make it up, nation-state building is unhinged from the stabilities of people and place. Following Appadurai (1996), then, and what he calls the 'slippery, nonlocalized' landscapes of group identity in a world of 'mobile sovereignties', the next section develops the preceding pointers to the twin vectors of dispossession and displacement in the Australian case. Its task is to historicize the conceit of 'host' in the dynamics of nation building in that country since colonial times. In this way we wish to suggest how postnational thinking destabilizes the narrative infrastructure of $a$ majority culture and its 'others,' and productively signals more mixed and unstable alliances of community and citizenry in this ex-colonial, Asia-Pacific nation.

\section{AUSTRALIAN NATION BUILDING IN TIME-SPACE PERSPECTIVE: A COLONIAL AND TRANSNATIONAL CIRCUIT}

The conceptual resources for theorizing nation building have been recast from a number of directions in recent years, including writings that conceive of nation-state formation in less 'state-centric' ways than previously (Basch et al., 1996; Balakrishnan, 1996; Munch, 2001). One useful strategy has been to historicize the nation state within the global relations of European modernity and colonialism, recognizing that the very concept of the 'nation state' was itself an export of Europe (Ang and Stratton, 1996). Many scholars have noted that there is no necessary congruence between the frontiers of political entities called 'states' and those of cultural communities called 'nations' (e.g. Collins, 1991; Bennett, 1998). In a context of 
globalizing flows of people, technology and capital, where such flows may be thought to undermine nationality and nationalism as categories of identification, economic organization and political constitution, there are equally indications that states look to build national identities as sources of public legitimation.

Take the example of Australia in the 1990s, when (as also described above) the tensions of an ex-colonial, immigration society erupted. The fragility of Labor-sponsored formulations of the nation state as 'multicultural' during the Keating regime, were richly registered, especially in the conservative heartlands of rural Queensland and New South Wales (Stratton, 1998). Recurring waves of populist white nationalism, including 'One Nation' hysteria, marked out the limits of consensual representations of Australia enunciated in the loudly trumpeted policy document Multicultural Australia: A Way Forward (Australia, Department of Immigration and Multicultural Affairs, 1997). This statement argued the (none too original) need to promote 'cultural diversity as a unifying force for Australia' (Australia, Department of Immigration and Multicultural Affairs, 1997; see also Canada, 1969). In turn, people of Asian background were variously branded as antithetical to Australian national culture, despite (or perhaps because of) the Keating Labor government's attempts to redefine Australia as 'part of Asia.' Aboriginal people were also angrily targeted as, at once, welfare sinks and land grabbers. Resentful discourses of 'white decline' (Hage, 1998) circulated through sections of Australian society, alongside various efforts to confront and resist them.

Such tensions easily succumb to a conventional analytical framework of 'race' and race relations, associated with many decades of psychologistic, sociological, political literatures. This framework, however, as Hage (1998) elaborated in White Nation, in identifying the problem of 'race' as the condition of being the racialized other, risks inscribing a spatial logic of nationally delimited us/them encounters - the 'us' implying a destiny that is 'here' and 'ours' as if to constitute a nodal point around which intercultural relations turn - and 'them' connoting a rupture or impact from 'out there'. Thus it is possible for Australians (of potentially all backgrounds) to argue in good faith that they are not racist and just 'defending their nation', that they have nothing against people of ' $y$ ' origin but do not want 'them' living in 'their' neighbourhoods or influencing 'their' children in 'their' schools, and so on. Whilst these are indeed instances of racism, their sources far exceed a problematic of 'difference' and 'sameness', as if each such position adheres to bodies that constitute an a priori nation. If race is, as San Juan (1998: 129) neatly defines it, a 'property of dominance-relations among groups', we need to remind ourselves continually that such relations are themselves as contingently and transnationally constructed and transformed, as the systems of raciology with which they interact.

For, in point of fact, far from being internal to the locus of a stably bound 
nation, the exclusionary politics of the Australian nation-building project, have been negotiated out of regimes of transnational reach. At least two such geo-historical regimes of differentiation and exclusion can be specified (though in the exceedingly condensed form possible in an article). Together, they release the potential of a postnational or diasporic imaginary for not only critically interrogating, but also for thinking, feeling and forging, connection across and beyond national borders. Picking up the vectors of 'dispossession' and 'displacement' mentioned earlier, we shall take each in turn: first modern colonial formation; and second, the contemporary era of transmigration.

\section{The colonial origins of the Australian nation}

Since Europe's Age of 'Discovery', the appropriation of land that provided the territory of 'New World' nation states, has been a distinct historical form of transnationality (Pagden, 1995). Numerous scholars have documented the intimate connections between capitalism, Christianity, and modernity in underwriting the diverse extensions of European empires abroad (e.g. Adas, 1989; Drayton, 2000). Such accounts detail a series of regimes of formidable power, conquest and struggle. Across the world that was considered 'New,' indigenous people were variously consigned to an anterior developmental space of premodern savagery. As such they were subject to, and in turn variously resisted, a range of practices, from mass murder, genocide, dispossession, and displacement to more benign gestures of protection and assimilation.

In the Australian case, the 1901 federation of the separate colonies into the Commonwealth of Australia was forged on the premise that its landmass had originally been terra nullius (not owned by anyone) - an idle wasteland awaiting settlement and conversion to productive use. The exclusion of non-white immigrants under the restrictive immigration act of 1901 also went hand in hand with Federation (Castles et al., 1988; Pettman, 1992). There were struggles among immigrants of Irish origin to share in the privileged status of Anglo settlers but, nonetheless, in a relatively short space of time, ethnic variation among immigrants of the British diaspora was homogenized beneath the myth of a mono (Anglo-Celtic) national culture. 'Australia' was seen as emerging, organically, from a British $\mathrm{racial} / \mathrm{cultural}$ heritage, in defiance and denial of the presence for at least 50,000 years prior to British settlement of over 100 Aboriginal language groups (Reynolds, 1998). Racial ideology became constitutive of colonial nation-state formation, with white settlers and their descendents complicit, to varying and sometimes contradictory degrees, in the imposition of alien power.

The popular representation of Australian nationhood as racially and culturally homogeneous was realized to a considerable extent in practice 
(and as mentioned earlier) by the 'White Australia' policy, while official assimilation policies also played their part in domesticating immigrant difference. By the 1970s, however, when the myth of a national identity dependent on a British origin could no longer be sustained in the face of demographic facts of all manner of diversities, 'Multiculturalism' became the new national cultural policy, against which 'Aboriginal Affairs' were pitted. By today, both such political discourses have been shaken by 'conservative mobilizations' of a traditional Anglo-Celtic ethnicity and their nostalgic claims to being a core national culture (see Johnson, 2002).

Even a radically potted account of the colonial making of 'Australia', such as we have just provided, needs also to register the myriad struggles of indigenous citizens to subvert colonialism's narrative and material power in the centuries since British 'settlement' (Flick, 1990; Huggins and Saunders, 1993; Langton, 1993; Moreton-Robinson, 2000). Colonialism's geographies in Australia, as elsewhere, are, and always have been, overlain with other cartographics of indigenous exchange, accommodation, appropriation, and resistance (Jacobs, 1996; Sparke, 1998). The postcolonial moment is registered, too, in the efforts of various Aboriginal authors to rewrite those histories that continue to centre white power (e.g. Anderson, 1997; Huggins, 1998); and to identify neo-colonialisms as they surface within contemporary white discourses, such as the latent terra nullius assumption that underpins Australian 'wilderness' discourses (Pearson, 1995; Langton, 1996).

A significant shift in the historical performance of white settler belongings has also developed around contemporary white imaginings of certain Australian environments as 'unpeopled' natures in need of protection. Corresponding with those aforementioned white anxieties over the recognition of native title, the 'ownership' and appropriate care of (by now) highly-prized Australian natures has become a new field of postcolonial contestation (Head, 2000). And it is a field that, as we shall see in more detail in the case study below, has generated the new (and fundamentally appropriative) subjectivity of Australian environmentalists as surrogate white custodial managers (Taylor, 2002).

\section{Global circuits of immigration}

The escalating flows of immigrants, knowledges and capital from the countries lining the Pacific Rim is a more contemporary transnational relationality in a world for which national borders matter less and less. In the Australian case, business migration from throughout Asia has had significant implications over the 1990s for the labour and housing markets of the eastern seaboard cities (Burnley, 1998; Inglis et al., 1992). In the case of Sydney, entrepreneurial migration from Hong Kong, Korea and Taiwan, constituted the major migrant category between 1995 and 1998 (Australia, 
Department of Immigration and Ethnic Affairs, 1995: 16). Notable within that stream were those so-called wealthy male 'astronauts' for whom 'here' and 'there' have been in no way dichotomous locations; businessmen who return to south-east Asia for work, while the rest of the family remain in typically high income suburbs (Pe-Pau et al., 1996). Such commuter migration has attracted a good deal of scholarly interest, not least because it upsets conventional images of a western modernization trajectory - of a linear move from a point somewhere in the 'undeveloped' world to a place in a more 'developed' country, where migrants are thought to face a period of difficult but irreversible 'integration' (Mar, 1998; Silvey and Lawson, 1999). More generally, as many scholars have already noted, such processes of transnational migration mean that dialogic encounters between 'immigrants' and 'citizens' can no longer be thought of in terms of 'peripheries' and 'centres', but rather as interdependent (Ong, 1999; Goldberg and Quayson, 2002).

National borders might be more pervious for some immigrant flows, but for other streams of working-class, refugee, and unskilled immigrants from Asia to Australia, constraint and confinement are more relevant images than fluidity and flow (Coughlan and Mcnamara, 1997). As the intensity and scale of global movements of migrants and money increase, the role of the state at times appears to recede, while at others, and certainly for sectors of people-flow that do not fit the business migration model, the state asserts itself with more strength. In that sense, border traversals hold the potential to conjure up less the voguish images of cosmopolitan hybridities, and more the darker ones of vigorously asserted and delimited sovereignties.

In the case of recent tensions over non-authorized entries into Australia, one can observe a shift from an international law/rights terminology of the 'refugee' to whom signatory nations have certain humanitarian obligations, to a more state-led or sovereignty-based terminology of 'asylum-seeker', whose plight is a matter of national discretion. Here, one recalls John Howard's remark and election slogan at the time of the Tampa affair: 'We, and we only, will decide who comes into our country and on what terms they come' (Howard, 2001). In other words, old power relations between advanced and more dependent economies are not so much erased by transnational flows of goods, capital, people and ideas, as reterritorialized in new configurations, sites and lived experiences.

The twin strands that have constituted the process of Australian nationstate building - of colonialism and transnational migrant flows - inflect the tensions over national belonging that are of interest to us in this article. As one of us has argued elsewhere (Anderson, 2000), and as we have earlier mentioned, thinking in terms of nation-building politics promises to move the understanding of inclusion/exclusion beyond a binary frame of racism toward or against 'others' - typically an Anglo-Celtic majority versus a 
range of non-white minorities (e.g. Vasta and Castles, 1996; Cowlishaw and Morris, 1997). Thinking of racism within a unitary national frame tends to rehearse the binary fix of a (nationally conceived) majority and its 'others'. It risks holding intact a certain narrative of the world within which an unnamed whiteness is anchored as the core culture of settler societies like Australia. This is also a narrative that likes to invoke a set of enduring core values as ones that distinguish the nation, core values such as tolerance and decency that John Howard reiterates as the essence of 'the Australian way', 'commonsense core values' from which, it is implied, Australian society today risks being cast adrift (Howard, 1999b; Hage, 2003, Chapter 5). The productive potential of a critical transnational perspective on nation building, however, is to unsettle the ground beneath any such privileged claims to ownership of a 'core' culture, casting the full range of migrants, settlers, and indigenes as subjects in process of struggle over rights to belong. As Essed and Goldberg (2002: 3) argue, the 'particularities of racial configurations' are everywhere linked in their complex expression to other systems of exclusion, requiring among other things 'a dialogue across continents and contexts'.

The language of multiculturalism has also tended to turn one's gaze inward, to the relationship between 'the migrant' and 'Australian society,' or 'Aboriginal' versus 'mainstream Australia.' That is, tensions over race and cultural difference risk being conceived within a problematic that is internal to the nation, to Australian history, Australian culture, to Australian racism. More generally the relations between groups are unhelpfully construed as 'domestic' matters, as if such affairs can be neatly separated from that which is 'foreign' (Agnew, 1999). Yet, the status positionings of majority and minority do not inhere in themselves, but entail hyphenated structures that relate them by inside/outside connection to Scotland, England, Greece, China, and so on, within a framework of indigenous tenure that is itself transected by rifts of region, 'mob' and kin. In this sense, the nation of 'Australia' is multiply traversed by diverse and heterogeneous presences, indigenous/migrant/settler - highlighting Braziel and Mannur's point (2003: 8 ), that diasporic dynamics are 'part of the nation itself' (while also the nation can be 'rewritten into the diaspora'). The categories of Old World/New World did not exist in a sharply contrastive relation that predated their mutual encounter, but rather came into being through a series of violent and non-violent articulations. These saw a landmass inhabited for some 50,000 years prior to British 'discovery' in the $1780 \mathrm{~s}$ defined as somehow 'New', and the British Isles (it perhaps bears recalling, separated from the continental land mass of Europe just 8000 years ago), defined as 'Old'. The point here is that the transmigration/colonial/world systems circuit as a whole is the defining identity-circuit in this vision, in a critical cultural studies conceived as fully internationalist and decolonized.

It should perhaps be quickly added that refiguring the terrain of nation 
building to take in transnational relations, does not produce a levelling of competing claims to belong. Certainly, indigenous Australians would be reluctant to have their epistemological stake in the nation cast in with 'migrant' communities, not to mention white settlers. But this would be to miss a point: that a postnational vision enlarges the ontological field for theorizing the often profoundly unequal exchanges out of which social arrangements in specific nation states have been produced. It follows that theorizing indigenous dispossession within power relations that exceed the boundaries of the nation state, far from weakening the logic for claims to special status, potentially strengthens and internationalizes them. The emergence of a global movement of indigenous people testifies to this (Centre for World Indigenous Studies, 2003). For transnational critique and action does not necessarily imply an erasure of 'the national'. To the contrary, thinking across nation-boundedness helps to clarify the continuities and discontinuities out of which are made the specificities of nation-state building struggles emerge.

\section{'THINKING' THROUGH THE LOCAL}

It will be clear from the foregoing sections that the processes of nation-state building take their character within a series of nested geographies: the global regimes of colonization, modernity, and transnational migration; world regional contexts (such as the Pacific Rim or the EU) that inflect their own framing specificities into migrant and money flows (and about which there is no scope in this article to treat); national policy contexts that mediate other scales of negotiation; and local geographies of lived experiences. These scales need to be conceived relationally, so as to clarify how the processes of nation building interact across a wide range of surfaces. Certainly there is scope for more academic, and perhaps especially, ethnographic accounts that critically link the contested claims of groups and institutions to space and place at the local level, to projects of national identity and belonging that do themselves exceed a national frame (in this vein, see the work of Holston and Appadurai, 1996; Low and LawrenceZuniga, 2003, Part V; Gow, 2005; White, 2002). ${ }^{1}$ Such research would move beyond theorizing such local conflicts within a problematic that reduces them to the dislocating 'impact' of immigrant bodies and thereby, once again, implies a too neat and flawed opposition of the domestic/foreign. According to Hesse (2000) in relation to the British context, an emphasis on tensions arising out of postwar immigration disavows their connection to the much longer-term making of white imperial Britishness (see also Gilroy's 1993 notion of the 'Black Atlantic' as an explicitly transnational/ historical space). 
Turning, then, to the local or community scale, we might note that citizenship is the primary formal indicator of national belonging. However, its granting by the state does not necessarily imply a communal will to include all citizens equally. Ip et al.'s (1997) study of Asian immigrants in Australia found that legal citizenship has not led to a sense of full incorporation at the neighbourhood scale, as indicated by their labelling and perception of themselves as 'migrants'. Similar findings emerged from an SBS Corporation study (Ang et al., 2002), in which a variety of non-Anglo immigrant and indigenous respondents either refused or were reluctant to self-identify as 'Australians'. Substantive citizenship, then, as distinct from formal citizenship, can thus be rich in non-juridical meanings that structure grids of social relations at the local level. In some cases of settler-colonial thinking in Australia, for example, standards of behaviour, including the ways houses are used, have been the basis for the admission or exclusion of Aboriginal people from city neighbourhoods and country towns (Rowse, 1999: 185-6). Dunn (2001: 7) notes that uneven constructions of citizenship are particularly common in local conflicts over land use. He refers to a common scenario in which '[r]esidents opposing developments will draw upon the argument that the out-siders ... or in-migrants are "non-locals"'. In a similar vein, white environmentalist determinations of appropriate local land use have formed the basis for regulating the extent and manner of Aboriginal participation in the management of parks across Australia (Baker et al., 2000; Taylor, 2002).

The 'spacings' of everyday life are thus key 'fields' within which qualitative determinations over national belonging are experienced, enacted, ordered, and resisted. In Australian metropolitan and rural settings, struggles over 'who belongs where' are routine. Whereas some groups are able to command the living and functional spaces of city and bush, asserting the voice of spatial ownership as a heritage, others have a much more precarious hold on them. Native Title holders, pastoralists, Aboriginal urban tenants, executives from Hong Kong and Australian-born descendants of Scottish origin do not by any means compete equally for citizenry rights. Nor do they share even access to the power to shape public landscapes and the character of local development, whether these be conservation areas, civic, corporate, or commemorative spaces. Furthermore, while some hybridized ethnicities have been successfully marketed and sold - so offering a representation of a cosmopolitan world beyond marked identities - other creolized cultures (for example of poverty-stricken indigeneity in Sydney's Redfern) have proven less attractive to capitalism's cannibalizing capacity (Fincher et al., 2002). The production and consumption of cosmopolitan urban spaces (such as Chinatowns) that seek to enact an inclusive universalism are fraught with these kinds of classed (and gendered) differentials. They can even amount to a colonial-style effacement of negatively evaluated forms of difference (Anderson, 1999). 
Such intercultural conflicts that have the appearance of being local, then, are never reducible to their ground-level specificities alone. Instead, such conflicts emerge out of, and do themselves constitute, broader deliberations over membership and voice that lie at the heart of nation-building politics. Such is their inherent 'multiscalar' complexity, of the kind that is best evoked through the type of grounded studies to which this article now turns. As microarticulations of dense time/space dynamics, they highlight Massey's (1993) 'extraverted' sense of 'the local', as co-present within a range of spatial and analytical scales.

\section{ETHNICITIES IN 'MULTISCALAR' FOCUS AT JERVIS BAY, NEW SOUTH WALES}

For a number of reasons, a longstanding dispute over the residential development of a dormant 'article estate' in Jervis Bay on the south coast of New South Wales (NSW), that began in the early 1990s and is still unresolved, is a clear illustration of how the multiscalar dimensions of Australian ethnicities are played out within the 'local' politics of nation building. More recently known as the Heritage Estates, this article estate was originally part of a larger constellation of 1915 urban subdivisions called 'Jervis Bay City' estates, intended to become the new nation's federal port city (Murphy, 1986). It is by now more a matter of coincidental interest that these article estates, conceived in Canberra (the political centre) but never built, had their origins in the birth of the nation. Of more interest to us is the fact that the Heritage Estates, as remnants of that earlier dream of nation, represent a particular set of extraneous political and cultural geohistorical convergences that typify the multiscalar nature of contemporary local struggles over national belonging in Australia. A brief exploration of the Heritage Estate dispute reveals that it is precisely that aforementioned series of nested geographies arising from the convergences of the global regimes of colonization, modernity and migration that have shaped these recent and very localized political struggles.

Of key postcolonial significance is the role that Jervis Bay's widely recognized Aboriginal heritage has played as a background to this dispute. This heritage has been well documented by western scholars (Sullivan, 1976; Egloff, 1990; Organ, 1990); actively maintained and publicized by local indigenous communities (Jerrinja Aboriginal Council and Wreck Bay Aboriginal Council, 1988; Wreck Bay Community and Renwick, 2000); and legally acknowledged through a number of Aboriginal land grants, culminating in the handing back of the prized Booderee National Park to the local Wreck Bay Aboriginal Community Council in 1995. The Heritage Estates land itself, while not containing any sites of special significance to 
the local Aboriginal communities (Stone, 1995) and without any nominated Aboriginal stakeholders, is nevertheless in close proximity to Aboriginal lands. It is pertinent to the Heritage Estates dispute (in ways that will soon be clarified) that, by the end of the 20th-century, Jervis Bay's indigenous heritage had become a routine point of reference for non-indigenous advocates wishing to authorize, highlight and promote the 'special nature' of the area (Pollard, 1973; Green and McGrath, 1990; Phelps et al., 1993; Jervis Bay Protection Committee, 1994).

This 'special nature', frequently associated with (originary) indigeneity and premodernity and evoked in scientific and touristic discourses (e.g. Green and McGrath, 1990; Jervis Bay Tourism Committee Inc., 2000), is often attributed to Jervis Bay's miraculous escape from the ravages of modernity. Since the 1940s, subsequent generations of naturalists, conservationists, scientists, environmentalists and concerned local citizens have successfully lobbied to prevent large-scale industrial and tourist development in Jervis Bay, and to secure statutory protection of large tracts of the area's highly acclaimed terrestrial and marine environments, along with key sites of indigenous cultural heritage. When protection of these prime areas was finally secured with the declaration of the Jervis Bay Marine Park in the late 1990s, the attention of many local environmentalists turned to ensuring that any future development of non-gazetted lands would also remain environmentally sensitive and sustainable.

The Jervis Bay Regional Alliance was formed in 1997 to function as a watchdog against any development that might pose a general threat to the local environment, and immediately targeted the Heritage Estates. This coalition of local groups pooled a wealth of environmental expertise, professional skills and extensive political networks. Apprehensions within the predominantly white local community had been aroused earlier in the 1990s when, despite their rural non-residential zoning, more than 1000 Heritage Estates blocks were sold off to individual purchasers. Local concerns escalated as the new landowners, eager to build and move to the area, organized themselves into a group called the Shoalhaven Landowners Association, and began to lobby the council to rezone their blocks. Although the Jervis Bay Regional Alliance primarily framed its opposition to this development in terms of environmental concerns (Jervis Bay Regional Alliance Inc., 1999), community submissions to local governments (Shoalhaven City Council, 1995), local council minutes (Shoalhaven City Council Minutes, 1992), discussions at Jervis Bay Regional Alliance meetings (field notes, July 1998, documented in Taylor, 2002) and interviews with Jervis Bay Regional Alliance and Shoalhaven Landowners Association members (conducted by Taylor in 1998-99 and documented in Taylor, 2002) made it clear that the diverse ethnicities and the recent immigrant (mainly southern European) profiles of this very large group of Heritage Estates absentee landowners was also a source of contention within the local 
community. Across such forums, (unmarked white) local opinions were expressed that suggested that as 'foreigners', the landowners could not fully appreciate Australian nature, nor the damaging effects that their domestic practices (such as building fences, clearing scrub, planting exotic species and erecting sheds) was having on these bushland blocks. Contested perceptions of appropriate land use appeared to be closely linked to a geocultural politics of community membership, local authorization and vying forms of Australian identity.

A multiscalar perspective on this highly 'extra-verted' local situation allows us to identify some of the ways in which the articulation of postcolonial and postnational positions form a distinctively Australian contemporary politics of national belonging and combine to produce contextually specific performances of whiteness. When we trace the spatialities within and between the (unidentified but noticeably white-settler) 'environmentalists' and (self-identified 'new' Australian) landowners' claims to this particular piece of land, we find some highly territorialized and intersubjective positionings emerging. Because the dispute was as much about authorization (who can speak for/make decisions about the land) as about appropriate land usage, it was also a contest over the successful establishment (in the case of the 'new' Australians) and naturalization (in the case of the white-settler Australians) of their respective relations to the land and the rights and responsibilities that flow from these.

Distinctive sets of correlations between national identity and relationships to the land emerged in interviews with representatives of both groups (documented in Taylor, 2002). To members of the Shoalhaven Landowners Association, the connections were quite straightforward: it was the act of purchasing the land that had finally materialized their Australian belongings and activated their citizenship rights. Through their interventions as 'concerned citizens', Alliance members, on the other hand, clearly assumed the role of national hosts or white managers of the multicultural national interest (as Hage, 1998 puts it). However, there was also a peculiarly postcolonial form of contemporary white-settler subjectivity that intersected with Alliance members' positioning as white/majority managers of the multicultural nation. In continuity with the aforementioned efforts of earlier (white) environmentalists to acknowledge the area's (originary) indigenous heritage, and because of the lack of a contemporary and embodied Aboriginal engagement in this dispute, members of the Jervis Bay Regional Alliance were able to assume custodial responsibilities for this land. White stewardship further naturalized their Australianness, authenticated their belongings, and added a potent moral imperative to their already established environmental expertise. Such a unique combination of authorizations allowed them to confidently speak on behalf of the land itself while simultaneously reconfirming the natural status of their perceived core Australian belongings. 
To date, the authorizations of these white land managers have held sway. After a decade of state and local government inquiries and commissions into the residential rezoning of the Heritage Estates, they remain undeveloped. At the same time, no decision has been made to resolve the dispute by repudiating the option to rezone (Shoalhaven City Council Planning and Policy Committee, 2004). The suspended nature of this dispute is an allegory of the ongoing struggles over place and belonging in the Australian nation that continue to be enacted locally. It highlights the 'extraverted' exclusionary politics at stake in these 'local' conflicts over national belonging. And finally, it allows us to contemplate the convergence of postcolonial cultural politics (based on indigenous and white settle relations to place) with postnational politics (based on non-Anglo multicultural negotiations over place and belonging).

\section{CONCLUSION}

In this article, we have sought to conceptually frame Australia's multiculture in terms of a notion of 'rights to belong' to the spaces made to ideologically stand as nations. Our path to this point has come by uncoupling the ideology and practice of nation building from the political institutions of the state, in such a way as to illuminate the multiscalar politics of belonging in Australia, as a case in point. Our major concern has been to develop the standpoint that the process implicates majorities and minorities alike: migrants, indigenes, asylum-seekers, plus those Anglo-Celtic visitors who claim the status of settler but whose subject position needs to be critically conceived as just as materially particular and historically specific as any other Australian subject position, as neither a core culture to be asserted nor one at risk of dispersal. A channel for dialogue across Aboriginal, multicultural, whiteness and settler studies is thereby cleared in the contested terrains of the nation-building project.

Ethnic pluralism has never made any sense as a problematic of 'them' alone. Acknowledging, as we have done in this article, that diverse ethnicities are collectively, albeit differentially, inserted in the fields of power and fantasy out of which nations are made, removes the subject/object relation of pluralist thought. This was Lisa Lowe's (1991) argument against the narrow and pernicious discourse of purity some time ago. There she highlighted the inherent prioritization of subject over object in binary constructions of difference, and argued instead for a vocabulary of 'heterogeneity' and 'multiplicity'.

Through transnational critique, we have gestured towards some of the specificities of contested Australian national identities that underscore the vicissitudes of whiteness as a cultural position and field of aspiration. In 
pointing to the complex interaction of indigeneity, migrancy, and white settler 'host' and appropriative 'custodial' positionings in Australia, we have been suggesting that Australia is a place where whiteness also struggles to defend and redefine its spatial and ontological territories. Australian whiteness may be a deeply sedimented mode of national subjectivity, but it is increasingly hard to conceal as the horizon of universal representation.

Future models of Australian multiculture cannot be adequately envisioned by simply acknowledging the co-existences within the space of the nation per se, as if national-boundedness was somehow pre-given. Nor would such models lie in renunciating 'difference', that is, through turning the other into the same. Rather, a new ethics of engagement across groups can be found by rendering more intelligible the transnational terrain of encounter, exchange, memory, desire and struggle out of which nations and national subjectivities are made, remade, and unmade. This is to propose an ethical vision to be sure, one that charts an idealized horizon worth fighting for, a future in which ethnic and raced demarcations are no longer divisive (Verges, 2002). But equally it is a vision that radically acknowledges - and often disappoints itself in - the demystifying exchanges of local life, and all their inherited materialities of history and geography.

\section{Note}

1 It should perhaps be noted here that local conflicts over national belonging in Australia have assumed another dimension in recent years. A growing awareness and even envy of indigenous ties to country, doubtlessly spurred on by the recognition of native title, has produced a corresponding desire on the part of nonindigenous Australians to reassert and naturalize their own connections to local places in order to reaffirm national belongings. Such moves are being increasingly explored in film (Perkins, 2001); literature (Mahood, 2000; Winton, 2002); and academia (Rose, 1997; Read, 2000; Taylor, 2002). See the case study later in the article.

\section{References}

Abrams, P. (1982) Historical Sociology. Bath: Pitman Press.

Adas, M. (1989) Machines as the Measure of Men. Ithaca, NY: Cornell University Press.

Agnew, J. (1999) 'The New Geopolitics of Power', in D. Massey, J. Allen and P. Sarre (eds) Human Geography Today, pp. 173-93. Cambridge: Polity.

Anderson, I. (1997) 'I, the "Hybrid" Aborigine: Film and Representation', Australian Aboriginal Studies 1: 4-14.

Anderson, K. (1999) 'Reflections on Redfern', in E. Stratford (ed.) Australian Cultural Geographies, pp. 67-84. Melbourne: Oxford University Press.

Anderson, K. (2000) 'Thinking Post-nationally: Dialogue across Multicultural, Indigenous, and Settler Spaces', Annals, Association of American Geographers 90(2): 381-91. 
Ang, I. (2003) 'From White Australia to Fortress Australia: The Anxious Nation in the New Century', in L. Jayasuriya, K. Walker and J. Gothard (eds) Legacies of White Australia, pp. 51-69. Crawley, WA: University of Western Australia Press.

Ang, I. and Stratton, J. (1996) 'Asianing Australia: Notes Toward a Critical Transnationalism in Cultural Studies', Cultural Studies 10(1): 16-36.

Ang, I., J.E. Brand, G. Noble and Wilding, D. (2002) Living Diversity: Australia's Multicultural Future. Artarmon, NSW: SBS Corporation.

Appadurai, A. (1996) Modernity at Large: Cultural Dimensions of Globalisation. Minneapolis, MN: University of Minnesota Press.

Australia, Department of Immigration and Ethnic Affairs (1995) 'Settlement Planning Information, June Update: Information on Migrants in New South Wales', Sydney.

Australia, Department of Immigration and Multicultural Affairs (1997) 'Multicultural Australia: The Way Forward', National Multicultural Advisory Council Issues Paper.

Bachelard, M. (1997) The Great Land Grab: What Every Australian Should Know About Wik, Mabo and the Ten Point Plan. South Melbourne: Hyland House.

Baker, R., J. Davies and E. Young, eds (2000) Working On Country: Contemporary Indigenous Management of Australia's Lands and Coastal Regions. South Melbourne: Oxford University Press.

Balakrishnan, G., ed. (1996) Mapping the Nation. London: Verso.

Basch L., N. Glick Shiller and C. Szanton Blanc (1996) Nations Unbound. Pennsylvania: Gordon \& Breach.

Bennett, D., ed. (1998) Multicultural States: Rethinking Difference and Identity. London and New York: Routledge.

Bonnett, A. (1997) 'Geography, "Race" and Whiteness: Invisible Traditions and Current Challenges', Area 29(3): 193-99.

Braziel, J. and A. Mannur, eds (2003) Theorizing Diaspora. Oxford: Blackwell.

Brennan, F. (2003) Tampering with Asylum: A Universal Humanitarian Problem. St Lucia: University of Queensland Press.

Brenner, N. (1998) 'Between Fixity and Motion: Accumulation, Territorial Organisation and the Historical Geography of Spatial Scales', Environment and Planning D: Society and Space 16(4): 459-81.

Burnley, I. (1998) 'Immigrant City, Global City? Advantage and Disadvantage Among Communities from Asia in Sydney', Australian Geographer 29(1): 49-70.

Canada (1969) Report of the Royal Commission on Bilingualism and Biculturalism. Ottawa: Queen's Printer.

Castles S., M. Kalantzis, B. Cope and M. Morrissey (1988) Mistaken Identity: Multiculturalism and the Demise of Nationalism in Australia. Sydney: Pluto Press.

Centre World Indigenous Studies (2003) Fourth World Journal [http://www. cwis.org].

de Certeau, M. (1984) The Practice Of Everyday Life. Berkeley, CA: University of California Press.

Cohen, E. (2003) 'Multiculturalism, Latin Americans and 'Indigeneity' in Australia', The Australian Journal of Anthropology 14(1): 39-88.

Collins, R. (1991) 'National Culture: A Contradiction in Terms?', Canadian Journal of Communications 16(2): 1-10. 
Coughlan, J. and D. McNamara, ed. (1997) Asians in Australia: Patterns of Migration and Settlement. Melbourne: Macmillan.

Cowlishaw, G. and B. Morris, ed. (1997) Race Matters: Indigenous Australians and 'Our' Society. Canberra: Aboriginal Studies Press.

Drayton, R. (2000) Nature's Government: Science, Imperial Britain and the 'Improvement' of the World. New Haven and London: Yale University Press.

Dunn, K. (2001) 'The Cultural Geographies of Citizenship in Australia', Geography Bulletin 33(1): 4-8. [http://www.fbe.unsw.edu.au/staff/Kevin.Dunn/publications/ 2001/KMD9.pdf]

Egloff, B. (1990) Wreck Bay an Aboriginal Fishing Community, Canberra: Aboriginal Studies Press.

Essed, P. and D.T. Goldberg, eds (2002) Race Critical Theories. Oxford: Blackwell.

Fincher, R., J.M. Jacobs and K. Anderson (2002) 'Rescripting Cities with Difference', in J. Eade and C. Mele (eds) Understanding the City: Contemporary and Future Perspectives, pp. 27-48. Oxford: Blackwell.

Fischer, M.J. (1999) 'Emergent Forms of Life: Anthropologies of Late or Postmodernities', Annual Review of Anthropology 28: 455-78.

Flick, B. (1990) 'Colonisation And Decolonisation: An Aboriginal Experience', in S. Watson (ed.) Playing The State: Australian Feminist Interventions, pp. 61-6. London: Verso.

Gelder, K. and J.M. Jacobs (1998) Uncanny Australia: Sacredness and Identity in a Postcolonial Nation. Melbourne: University of Melbourne Press.

Gilroy, P. (1993) Black Atlantic: Modernity and Double Consciousness. London: Verso.

Goldberg, D. and A. Quayson, eds (2002) Relocating Postcolonialism. Oxford: Blackwell.

Gooder, H. and J. Jacobs (2000) 'On the Border of the Unsayable: The Apology in Postcolonizing Australia', Interventions 2(2): 229-47.

Gow, G. (2005) 'Rubbing Shoulders in the Global City: Refugees, Citizenship and Multicultural Alliances in Fairfield, Sydney', Ethnicities 5(3): 386-405.

Green, R. and M. McGrath (1990) Jervis Bay Marine Park: A Proposal by Australian Conservation Foundation. Canberra: Australian Conservation Foundation.

Hacking, I. (2002) Historical Ontology. Cambridge, MA: Harvard University Press.

Hage, G. (1998) White Nation: Fantasies of White Supremacy in a Multicultural Society. Sydney: Pluto Press.

Hage, G. (2003) Against Paranoid Nationalism: Searching For Hope In A Shrinking Society. Sydney: Pluto Press.

Hall, S. (1994) 'Cultural Identity and Diaspora', in P. Williams and L. Chrisman (eds) Colonial Discourse and Post-colonial Theory: A Reader, pp. 392-403. New York: Columbia University Press.

Head, L. (2000) Second Nature: The History And Implications Of Australia As Aboriginal Landscape. Syracuse and New York: Syracuse University Press.

Hesse, B. (2000) 'Un/settled Multiculturalisms', in B. Hesse (ed.) Un/settled Multiculturalism: Diasporas, Entanglements, Transruptions, pp. 3-25. London: Zed Books.

Holston, J. and A. Appadurai (1996) 'Cities and Citizenship', Public Culture 8: 187-204. 
Howard, J. (1999a) A New Agenda for Multicultural Australia, Prime Minister's Forward [http://www.immi.gov.au/multicultural/_inc/pdf_doc/agenda/agenda.pdf].

Howard, J. (1999b) 'The Australian Way', Federation Address 28 January [http: //www.pm.gov.au/news/speeches/1999/federationaddress2801.htm].

Howard, J. (2001) 'Prime Minister of Australia, John Howard, Newsroom' [http://www.pm.gov.au/news/interviews/2001/interview1434.htm].

Huggins, J. (1998) Sister Girl. St Lucia: University of Queensland Press.

Huggins, J. and K. Saunders (1993) 'Defying The Ethnographic Ventriloquists: Race, Gender And The Legacies Of Colonialism', Lilith 8: 60-70.

Inglis, C. and C-T. Wu (1992) 'The "New" Migration of Asian Skills and Capital in Australia', in C. Inglis, S. Gunaskeran, G. Sullivan and C-T. Wu (eds) Asians in Australia, pp. 193-230. St Leonards: Allen and Unwin.

Ip, D., C. Inglis and C-T. Wu (1997) 'Concepts of Citizenship and Identity Among Recent Asian Immigrants to Australia', Asian and Pacific Migration Journal 6(3-4): 363-84.

Jacobs, J.M. (1996) Edge of Empire: Postcolonialism and the City. London: Routledge.

Jerringa Local Aboriginal Council and Wreck Bay Aboriginal Council (1988) We Come From the Land (videotape). Sydney: Common Films.

Jervis Bay Protection Committee (1994) Visions of Jervis Bay (videotape). Nowra: Jervis Bay Protection Committee.

Jervis Bay Regional Alliance Inc. (1999) 'Submission to Commission of Inquiry into the Heritage Estates, Jervis Bay', paper presented to the Submission of Inquiry into the Heritage Estates, Jervis Bay, Vincentia, May-June.

Jervis Bay Tourism Committee Inc. (2000) Jervis Bay Secrets [http://www. jervisbaytourism.com.au/].

Johnson, C. (2002) 'The Dilemmas of Ethnic Privilege: A Comparison of "British", "English" and "Anglo Celtic" Identity in Contemporary British and Australian Political Discourse', Ethnicities 2(2): 163-88.

Jonas, B. (2000) Native Title Report 1999. Sydney: Aboriginal and Torres Strait Islander Social Justice Commissioner, Human Rights and Equal Opportunity Commission.

Kohler, B. and M. Wissen (2003) 'Glocalizing Protest: Urban Conflicts and Global Social Movements', International Journal of Urban and Regional Research 27(4): 942-51.

Langton, M. (1993) 'Well I Heard It On The Radio And I Saw It On The Television'. Sydney: Australian Film Commission.

Langton, M. (1996) 'What Do We Mean By Wilderness? Wilderness And Terra Nullius In Australian Art', The Sydney Papers, The Sydney Institute 8(1): 10-31.

Langton, M. (2003) 'The Nations of Australia', in S. Vizard, H. Martin and T. Watts (eds) Australia's Population Challenge, pp. 242-56. Camberwell, Victoria: Penguin.

Low, S. and D. Lawrence-Zuniga, eds (2003) The Anthropology of Space and Place: Locating Culture. Oxford: Blackwell.

Lowe, L. (1991) 'Heterogeneity, Hybridity, Multiplicity: Marking Asian American Differences', Diaspora: A Journal of Transnational Studies 1(1): 24-44.

Mahood, K. (2000) Craft For A Dry Lake. Sydney: Anchor.

Malkki, L. (1992) 'National Geographic: The Rooting of Peoples and the 
Territorialization of National Identity Among Scholars and Refugees', Cultural Anthropology 7(1): 24-44.

Mar, P. (1998) 'Just the Place is Different: Comparisons of Place and Settlement Practices of Some Hong Kong Migrants in Sydney', The Australian Journal of Anthropology 9(1): 58-73.

Mares, P. (2002) Borderline, Reportage Series. Sydney: University of New South Wales Press.

Massey, D. (1993) 'Power-Geometry and a Progressive Sense of Place', in J. Bird, B. Curtis, T. Putnam and L. Tickner (eds) Mapping the Futures: Local Cultures, Global Change, pp. 59-69. London: Routledge.

Massey, D. (2000) 'Travelling Thoughts', in P. Gilroy, L. Grossberg and A. McRobbie (eds) Without Guarantees: In Honour of Stuart Hall, pp. 225-32. London and New York: Verso.

Moreton-Robinson, A. (2000) Talkin' Up The White Woman. St Lucia: University of Queensland Press.

Munch, R. (2001) Nation and Citizenship in the Global Age. New York: Palgrave.

Murphy, G. (1986) 'Henry F. Halloran: Dealer in Land and Dreams', Canberra Historical Journal, New Series, 17: 1-88.

Nicholl, F. (2001) From Diggers to Drag Queens: Configurations of Australian National Identity. Annandale NSW: Pluto Press.

Ong, A. (1999) Flexible Citizenship: The Cultural Logics of Transnationality. Durham, NC: Duke University Press.

Organ, M., ed. (1990) A Documentary History of the Illawarra and South Coast Aborigines 1770-1850. Wollongong: Aboriginal Education Unit, Wollongong University.

Pagden, A. (1995) Lords of the World: Ideologies of Empire in Spain, Britain and France c.1500-1800. New Haven, CT: Yale University Press.

Pearce, R.H. (1988[1953]) Savagism and Civilisation: A Study of the Indian and the American Mind. Berkeley, CA: University of California Press.

Pearson, N. (1995) 'Cape York Peninsular: The Land Needs Its People', Arena Magazine 19: 39-41.

Pe-Pau, R., C. Mitchell, R. Iredale and S. Castles (1996) Astronaut Families and Parachute Children: Migration between Hong Kong and Australia. Canberra: Australian Government Publishing Service.

Perera, S. (2002) 'A Line in the Sea: The Tampa, Boat Stories and the Border', Cultural Studies Review 8(1): 11-27.

Perera, S. and J. Pugliese (1996) 'The Limits of Multicultural Representation', Communal/Plural 4: 91-113.

Perkins, R. (2001) One Night The Moon (videotape). Sydney: Dendy Films.

Pettman, J. (1992) Living in the Margins: Racism, Sexism and Feminism in Australia. Sydney: Allen \& Unwin.

Phelps, L., R. Watson and S. Salmon (1993) 'Jervis Bay: No Place for Arms', Habitat 21(4): 2-4.

Pollard, D. (1973) Jervis Bay: The Future? Special Publication of Australian Littoral Society. Glebe: Tomato Press.

Read, P. (2000) Belonging: Australians, Place, and Aboriginal Ownership. Cambridge and Melbourne: Cambridge University Press.

Reynolds, H. (1998) This Whispering In Our Hearts. St Leonards: Allen and Unwin. 
Rose, D.B. (1997) 'Australia Felix Rules Ok!', in G. Cowlishaw and B. Morris (eds) Race Matters: Indigenous Australians And 'Our' Society, pp. 121-37. Canberra: Aboriginal Studies Press.

Rowse, T. (1999) White Flour, White Power. Cambridge: Cambridge University Press.

San Juan, E. (1998) Beyond Postcolonial Theory. New York: St Martins Press.

Shaw, W.S. (2001) 'Ways of Whiteness: Negotiating Settlement Agendas in (Post)colonial Inner Sydney', PhD thesis, School of Anthropology, Geography and Environmental Studies, University of Melbourne.

Shoalhaven City Council Minutes (1992) 'First addendum report of Planning Services Manager', 15 December, Shoalhaven, NSW.

Shoalhaven City Council (1995) 'Environmental Study Heritage Estates: Summary of Submissions and Issues Following Exhibition from 28 September to 30 December 1994', Planning Services Division File 92/3277, Shoalhaven, NSW.

Shoalhaven City Council Policy and Planning Committee (2004) 'Heritage Estates Rezoning Investigation Outcomes (Draft LEP No LP 157)', Shoalhaven, NSW [http://www.shoalhaven.nsw.gov.au/council/pubdocs/papers/2004Jan_Jun/200402 10pp.pdf].

Silvey, R. and V. Lawson (1999) 'Placing the Migrant', Annals, Association of American Geographers 89(1): 121-32.

Stone, T. (1995) 'A Preliminary Archaeological Investigation of the Heritage Estates Subdivision near Old Erowal Bay, N.S.W.', report commissioned by Shoalhaven City Council, NSW.

Sparke, M. (1998) 'A Map that Roared and an Original Atlas: Canada, Cartography and the Narration of Nation', Annals, Association of American Geographers 88(3): 463-95.

Stratton, J. (1998) Race Daze: Australia in Identity Crisis. Sydney: Pluto Press.

Sullivan, M.E. (1976) 'Archaeological Occupation Site Locations on the South Coast of NSW, Archaeology and Physical Anthropology', Oceania 11(1): 56-69.

Swyngedouw, E. (1997) 'Neither Global nor Local: 'Glocalization' and the Politics of Scale', in K.R. Cox (ed.) Spaces of Globalization: Reasserting the Power of the Local, pp. 137-66. New York and London, Guilford Press.

Taylor, A. (2002) 'Struggles Over Jervis Bay: A Postcolonial Geography Of Place And Belonging', PhD Thesis, University of New South Wales.

Vanstone, A., (2003) 'Border Protection' [http://www.minister.immi.gov.au/borders/ index.htm].

Vasta, E. and S. Castles, eds (1996) The Persistence of Racism in Multicultural Australia. Sydney: Allen \& Unwin.

Verges, F. (2002) 'Post-scriptum', in T. Goldberg and A. Quayson (eds) Relocating Postcolonialism, pp. 349-58. Oxford: Blackwell.

White, E.J. (2002) 'Forging African Diaspora Places in Dublin's Retro-Global Spaces: Minority Making in a New Global City', City 6(2): 250-70.

Wreck Bay Community and C. Renwick (2000) Geebungs and Snake Whistles: Koori People and Plants of Wreck Bay. Canberra; Aboriginal Studies Press, AIATSIS.

Winton, T. (2002) Dirt Music. London: Picador. 
KAY ANDERSON is Professor of Cultural Research in the Centre for Cultural Research, University of Western Sydney. Address: Centre for Cultural Research, University of Western Sydney, Parramatta Campus, Sydney, NSW, Australia. [email: k.anderson@uws.edu.au]

AFFRICA TAYLOR is a Lecturer in Sociology and Cultural Studies within the teacher education program at University of Canberra. Address: School Education and Community Studies, University of Canberra, ACT 2601, Australia. [email: affrica.taylor@canberra.edu.au] 